\title{
EVALUASI KURIKULUM 2014 JURUSAN PENDIDIKAN SENI TARI
}

\author{
Ni Nyoman Seriati, Kuswarsantyo, Marwanto, Rumiwiharsih \\ Fakultas Bahasa dan Seni, Universitas Negeri Yogyakarta \\ Email: ni_nyoman seriati@uny.ac.id
}

\begin{abstract}
Abstrak
Tujuan Penelitian evaluasi kurikulum 2014 Jurusan Pendidikan Seni Tari untuk: (1) Mendeskripsikan hasil evaluasi kurikulum Prodi Pendidikan Seni Tari yang dibutuhkan masyarakat. (2) Mendapatkan data dari alumni/stake hoder mahasiswa untuk mengembangkan konsep kurikulum yang ideal untuk menghasilkan lulusan Prodi Pendidikan Seni Tari yang kompetitif. Penelitian ini menggunakan pendekatan kualitatif. Realisasi dari penelitian ini adalah riset evaluasi yang memiliki arah tujuan untuk memperoleh umpan balik dari hasil kebijakan. Objek penelitian adalah kurikulum 2014 pada Jurusan Pendidikan Seni Tari yang akan dilihat dari isi kurikulum, sebaran mata kuliah pada setiap semester, dan diskripsi mata kuliah. Subjek penelitian ini berjumlah 30 orang yang terdiri dari alumni Prodi Pendidikan Seni Tari dan stake holder 15 orang dan mahasiswa Jurusan Pendidikan seni Tari 15 orang. Setting penelitian ini dilaksanakan di Jurusan Pendidikan Seni Tari Fakultas Bahasa dan Seni Universitas Negeri Yogyakarta. Teknik pengumpulan data dilakukan melalui FGD pertemuan langsung dengan responden. Analisis data menggunakan analisis deskriptif kualitatif. Hasil penelitian terhadap evaluasi kurikulum 2014 Prodi Pendidikan Seni Tari mencangkup tiga bidang yaitu: (1) isi kurikulum, (2) sebaran mata kuliah, (3) deskripsi mata kuliah. Uji materi kepada alumni dan stake holder tentang isi kurikulum didapatkan hasil bahwa kerikulum perlu ditambahkan mata kuliah Apresiasi Seni, sementara hasil uji materi dengan mahasiswa dipandang perlu untuk menambahkan mata kuliah olah tubuh dan koreografi. Uji materi pada sebaran mata kuliah responden dari mahasiswa merekomendasikan untuk menempatan mata kuliah seminar pada semester tujuh. Untuk uji materi tentang deskripsi mata kuliah kepada alumni dan stake holder diperoleh hasil untuk mencantumkan pendidikan karakter dan nasionalisme mata kuliah PKN, Kewarganegaraan, Agama. Penilaian pada mata kuliah praktik perlu dilengkapi dengan penilaian sikap. Sedangkan dari mahasiswa diperoleh hasil untuk perlu ditambahkan tentang pengelolaan sanggar mata kuliah kewirausahaan.
\end{abstract}

Kata kunci: evaluasi, kurikulum 2014, prodi pendidikan seni tari

\section{CURRICULUM 2014 EVALUATION: DANCE EDUCATION}

\begin{abstract}
The purposes of this study were to: (1) describe the result of dance art education study program curriculum evaluation needed by the community; (2) get data from stake holders or alumni to develop ideal curriculum concepts to produce competitive dance arts education study program graduates. This was a qualitative study. The realization of this research was evaluation research that has a direction to get feedback from the policy results. The object of the study was curriculum 2014 in the dance art education study program that will be seen from its content, distribution of courses for each semester, and course descriptions. The subjects of the research were 30 people consisting of alumni of the dance arts education study program: 15 stakeholders and 15 students of the department of dance art education study program. Results on the evaluation of curriculum 2014 in dance art education study program consist of 3 fields: (1) the content of
\end{abstract}


the curriculum; (2) course distribution; (3) course description. Material testing on the alumni and stakeholders about the content of the curriculum revealed that art appreciation course should be added in the curriculum; while material testing on the students suggested adding body training and choreography course. Material testing on the students about the course description recommended putting seminar course on the seventh semester. Then, material testing on alumni and stake holders about course description suggested adding character education and nationalism on citizenship education, citizenship, and religion courses. Scoring on practical courses need to be completed with attitude assessment. Nevertheless, material testing on students showed a need to add management of entrepreneurship courses.

Keywords: evaluation, curriculum 2014, dance education study program

\section{PENDAHULUAN}

Pendidikan merupakan hak seluruh anggota masyarakat yang dilakukan sepanjang hidupnya, baik yang bersifat formal maupun non formal. Pendidikan bersifat membebaskan, maksudnya pendidikan harus berhubungan dengan dunia nyata. Peserta didik diajak untuk berpikir dan menyadari apa yang sesungguhnya terjadi.

Dalam rangka ikut mencerdaskan kehidupan bangsa, lembaga yang bergerak di bidang pendidikan perlu tanggap mensikapinya agar para lulusan mengetahui sesungguhnya apa yang terjadi di masyarakat. Guna memenuhi kebutuhan pasar kerja perguruan tinggi menyikapi dengan membuka program studi yang relevan. Untuk menghasilkan lulusan yang memiliki kompetensi diusahakan dengan selalu meninjau kurikulum untuk mengikuti perkembangan pasar.

Program Studi Pendidikan Seni Tari Fakultas Bahasa dan Seni (FBS) Universitas Negeri Yogyakarta adalah salah satu program studi yang mendidik para mahasiswa dalam bidang seni tari. Program Studi ini dibuka untuk menghasilkan lulusan yang berkualitas dan memenuhi kompetensi yang dibutuhkan oleh stake holder. Untuk memenuhi kebutuhan pasar khususnya dunia pendidikan mulai dari tingkat dasar sampai sekolah menengah, bahwa seni masuk dalam kelompok mapel seni budaya. Adapun isian materinya mencangkup empat bidang seni yaitu: tari, musik, rupa, dan drama. Untuk tetap menjaga kesatuan NKRI materi-materi dari ketiga seni tersebut diarahkan pada apresiasi seni nusantara.
Kurikulum 2014 pada Program Studi Pendidikan Seni Tari mengimplentasikan dari kurikulum NKRI dengan memasukkan materi nusantara terutama pada mata kuliah bidang keahlian (tari). Mata kuliah ini masuk pada kelompok tari Nusantara. Adapun materi terdiri dari: tari Betawi, Sunda, Sumatera, Bali, NTT, Makasar (Sulawesi), Kalimantan, dan Papua. Sedangkan untuk mata kuliah pendukung seperti karawitan baru pada karawitan Jawa (Yogyakarta dan Surakarta). Sementara pada mata kuliah teori isu-isu tentang nusantara terintegrasi pada beberapa mata kulaih seperti: pengetahuan tari, sejarah tari, sosiologi, dan antropolosi tari. Berkaitan dengan hal tersebut Program Studi Pendidikan seni Tari selain menghasilkan tenaga yang profesional dalam bidangnya kurikulum juga diharapkan seimbang dalam aspek sikap, pengetahuan, dan keterampilan.

Seiring perkembangan jaman yang berubah cukup dinamis kedewasaan manusia berkembang dengan cepat sehingga kurikulum yang ada dirasa kurang atau belum mampu untuk menjawab kebutuhan pasar. Oleh karenanya sangat penting dilakukan evaluasi terhadap kurikulum agar dapat memenuhi kebutuhan dan perkembangan jaman.

Berkaitan dengan kondisi tersebut kurikulum 2014 Pendidikan Seni Tari yang sedang berjalan saat ini perlu dilakukan evaluasi agar sesuai dengan kebutuhan dan pekembangan jaman. Evaluasi dapat dilakukan baik terhadap materi maupun sebaran mata kuliahnya pada setiap semester. Oleh karenanya 
penelitian ini akan melaksanakan evaluasi terhadap kurikulum 2014 pada Program Studi Pendidikan Seni Tari. Sesuai dengan peraturan yang tercatum pada standar mutu UNY tercantum bahwa evaluasi dan penyempurnaan terhadap kurikulum dilakukan secara berkala dalam kurun waktu 5 (lima) tahun. (standar mutu UNY, 2014: 7)

\section{METODE}

Penelitian ini menggunakan pendekatan kualitatif. Rancangan atau desain penelitian dalam arti sempit dimaknai sebagai suatu proses pengumpulan dan analisis penelitian, selanjutnya dalam arti luas rancangan penelitian meliputi proses perencanaan dan pelaksanaan penelitian. Realisasi dari penelitian ini adalah riset evaluasi yang memiliki arah tujuan untuk memperoleh umpan balik dari hasil kebijakan. Riset evaluasi ini dapat digunakan untuk membantu program dalam jangka panjang, terutama untuk menjamin sustainabilitasnya (keberlanjutannya), (Samsul Hadi, 2011: 101).

Pendekatan lain yang digunakan adalah pendekatan tekstual. Teks bukan cara melainkan sumber. Akal adalah poros utama pengetahuan. Tanpa akal maka persepsi hanya sebatas gambaran partikel-partikel yang tak memiliki relasi satu sama lain. Ibarat kamera yang hanya merekam gambar-gambar. Tanpa akal baris-baris yang direkam oleh mata pada lembaran-lembaran buku ini hanya sebatas warna hitam di atas kertas. Begitu pula kiranya pembacaan teks ayat-ayat dalam Kitab Suci, tanpa akal hanya sebatas tulisan di atas kertas. Yang memungkin adanya makna yang bisa dipahami dan dimengerti karena adanya akal. Itu sebabnya, dalam agama Islam misalnya, Tuhan tidak mewajibkan apa-apa bagi orang yang tidak berakal, alias belum balig atau gila. Di antara fungsi akal yang paling utama adalah menemukan adanya relasi logis antara detildetil pengetahuan yang masih dalam bentuk persepsi-persepsi, setidaknya persamaanpersamaan dan perbedaannya, merumuskan dan menyusunnya untuk membangun sebuah pemahaman yang dapat dimengerti sebagai kesimpulan. Sia-sia saja anda membaca lembaran-lembaran buku ini jika kemudian tidak berhasil memperoleh kesimpulan. Ini mempertegas betapa tidak relevannya pandangan yang menganggap rasionalitas menjauhkan dari originalitas pemahaman agama. Tanpa akal teks tidak bisa dipahami dan tidak bisa dimengerti apalagi menerapkan maknanya (Zulkarnaen Diran, 2016: 21)

Penelitian ini dilakukan untuk menghasilkan evaluasi secara komprehensif terkait dengan kurikulum 2014 yang dilaksanakan di Jurusan Pendidikan Seni Tari FBS UNY. Hal ini sesuai dengan tujuan dari digunakannya metode penelitian ini yaitu mengungkap fakta, keadaan, fenomena, variabel dan keadaan yang terjadi saat penelitian berjalan dan menyuguhkan apa adanya. Sejalan dengan hal tersebut, Sukmadinata (2008:100-101) mengungkapkan tujuan penelitian kualitatif yaitu untuk:

1. Mendeskripsikan proses kegiatan pendidikan berdasarkan apa yang terjadi di lapangan sebagai bahan kajian lebih lanjut untuk menemukan kekurangan dan kelemahan pendidikan sehingga dapat ditentukan upaya penyempurnaannya.

2. Menganalisis dan menafsirkan suatu fakta, gejala dan peristiwa pendidikan yang terjadi di lapangan sebagaimana adanya dalam konteks ruang dan waktu serta situasi lingkungan pendidikan secara alami.

Dengan demikian, dapat dikatakan, bahwa tujuan penelitian kualitatif adalah ingin menggambarkan peristiwa yang terjadi di lapangan dan terjadi secara alami atau apa adanya, dan juga mengelompokkan objek-objek studi. Sementara itu, Nawawi (dalam Soejono. 2005: 22) mengungkapkan bahwa penelitian kualitatif jenis deskriptif eksploratif memiliki dua ciri pokok yaitu (1) memusatkan perhatian pada masalah-masalah yang ada pada saat penelitian dilakukan atau bersifat aktual; dan (2) untuk menggambarkan fakta-fakta tentang masalah yang diselidiki sebagaimana adanya dan diikuti dengan interpretasi rasional.

Terkait penelitian ini dianalisis dan diidentifikasikan secara cermat dan menggali suatu fenomena tertentu untuk selanjutnya 
mengumpulkan informasi secara lengkap dengan menggunakan berbagai prosedur pengumpulan data berdasarkan waktu yang telah ditentukan dan dilakukan secara alami (Stake, 2009; Creswell, 2010). Dalam melakukan penelitian kualitatif, suatu kegiatan ataupun aktivitas hanya dapat dipahami sebaikbaiknya apabila diamati, dan kegiatan ataupun aktivitas itu terjadi secara alami (natural). Dengan demikian, penelitian ini dilaksanakan dengan menganalisis dan mengidentifikasi dokumen-dokumen perkembangan [perubahan kurikulum 2014 yang diberlakukan di Prodi Pendidikan Seni Tari.

Objek penelitian adalah kurikulum 2014 pada Jurusan Pendidikan Seni Tari yang akan dilihat dari isi kurikulum, sebaran mata kuliah pada setiap semester, dan diskripsi mata kuliah.

Subjek penelitian ini berjumlah 30 orang yang terdiri dari alumni Prodi Pendidikan Seni Tari, stake holder dan mahasiswa Jurusan Pendidikan Seni Tari masing-masing berjumlah 15 orang. Adapun para alumni yang telah bekerja baik sebagai guru seni di pemerintahan maupun swasta, sedangkan stake holder para pemakai lulusan yaitu kepala sekolah sesuai tempat bekerja berjumlah 15 orang. Untuk mahasiswa perwakilan diambil dari tiga angkatan yaitu semester tiga, lima, dan tujuh masing-masing angkatan mewakili 5 orang sehingga berjumlah 15 orang. Dari perwakilan ini diharapkan dapat memberikan kontribusi terhadap evaluasi kurikulum 2014 Prodi Pendidikan Seni Tari. Penelitian ini akan dilaksanakan di Jurusan Pendidikan Seni Tari, Fakultas Bahasa dan Seni, Universitas Negeri Yogyakarta.

Pengumpulan data penelitian dilakukan melalui pertemuan langsung dengan responden dan beberapa ada yang dikirim melalui email. Untuk menjaring data lewat dosen dilakukan melalui FGD. Pengumpulan data untuk mahasiswa dilakukan dengan tatap muka langsung. Untuk mendapatkan masukan para responden deberi kurikulum untuk dicermati baik isian matakuliah, sebaran pada setiap semester, dan diskripsi mata kuliah.
Analisis data penelitian ini menggunakan deskriptif kualitatif. Analisis kualitatif digunakan untuk mendeskripsikan data-data yang berupa kata-kata, masukan tertulis dari para responden. Tahap analisis yang telah dilakukan dengan penyebaran angket untuk mengetahui pemahaman para pengguna kurikulum baik stake holder, guru, dan siswa. Hasil angket kemudian dianalisis untuk mengetahui kecenderungan pendapat tentang kurikulum yang diterapkan.

Tahap berikutnya untuk mengetahui pemahaman maksud tujuan kurikulum dilakukan wawancara terhadap pengguna, guru dan siswa. Arah pertanyaan untuk mengetahui sejauhmana pemahaman kurikulum dan implementasinya di lapangan. Di sini terlihat pentingnya peran stakeholder, guru dansiswa memahami secara utuh agar arah tujuan kurikulum tersebut dapat tepat sasaran dan menghasilkan anak didik yang cerdas.

\section{HASIL DAN PEMBAHASAN}

Pengembangan kurikulum 2014 Prodi Pendidikan Seni Tari didasarkan pada beberapa hal yakni: (1) perkembangan ilmu pengetahuan, teknologi, dan seni yang menuntut untuk selalu meng-update kurikulum secara periodik; (2) Kurikulum 2009 belum dikembangkan berdasarkan KKNI; dan (3) berdasarkan hasil tracer study serta hasil evaluasi terhadap kurikulum on going diketahui adanya beberapa kelemahan yang perlu diperbaiki agar tetap relevan dengan kebutuhan lapangan.

Profil lulusan dan capaian pembelajaran (Learning Outcame) yang dirumuskan oleh Program Studi Pendidikan Seni Tari pada kurikulum 2014 sebagai berikut:

1. Profil Lulusan.

a. Profil lulusan S 1 Pendidikan Seni Tari sebagai profil utamanya adalah sebagai pendidik Seni Tari profesional di SMP/ MTs dan SMA/MA/SMK yang memiliki kompetensi kepribadian, profesional, sosial, dan pedagogik dalam menjalankan tugasnya.

b. Penari profesional yang memiliki sikap disiplin dan tanggungjawab atas 
pekerjaannya, serta mampu merefleksikan fenomena kehidupan seni tari dalam masyarakat.

c. Koreografer/penata tari profesional yang memiliki kompetensi manajerial, interaksi sosial, dan komunikasi sosial dalam berkarya seni, serta memiliki tanggungjawab atas karya ciptanya, terutama pada bidang koreografi anak dan remaja.

d. Wirahusahawan di bidang seni pertunjukan profesional khususnya bidang pengelolaan sanggar yang dalam menjalankan tugasnya memiliki kompetensi manajerial, sosial, dan interaksi sosial.

\section{Capaian Pembelajaran (Learning Outcame)} Capaian pembelajaran Program Studi Pendidikan Seni Tari mencakup aspek: (1) sikap, (2) pengetahuan, (3) keterampilan, dan (4) tanggungjawab dan kewenangan yang diperoleh melalui proses pembelajaran dalam setiap matakuliah yang disampaikan.

\section{Struktur kurikulum dan sebaran Mata} kuliah

Struktur kurikulum 2014 Program Studi Pendidika Seni Tari mencangkup lima bidang yaitu; (1) kelompok Mata Kuliah Umum (MKU), (2) kelompok Mata Kuliah Dasar Kependidikan (MDK), (3) kelompok Mata Kuliah Keterampilan Proses Pembelajaran (MKKPP), dan (4) kelompok Mata Kuliah Bidang Keahlian (MKBK), dan kelompok Mata Kuliah Pengembangan Pendidikan (MKPP). Dari kelima kelompok mata kuliah ini dituangkan menjadi 145 sks dengan komposisi teori 79 sks, praktik 59 sks, dan lapangan 7 sks. Jumlah 145 sks ini ditempuh dalam delapan semester dengan jumlah sks pada setiap semester berbeda-beda. Untuk semester 1 ada 22 sks, semester 2 ada 21 sks, semester 3 ada 22 sks, semester 4 ada 22 sks, semester 5 ada 20 sks, semester 6 ada 21 sks, semester 7 ada 10 sks, dan semester 8 ada 6 sks khusus mata kuliah Tugas akhir. Sebaran mata kuliah pada setiap semester dengan mempertimbangkan komposisi antara mata kuliah teori dan praktik serta mata kuliah yang berjenjang seperti misalnya mata kuliah Koreografi 1, 2, dan 3.

Disamping mata kuliah utama kurikulum 2014 ini menyediakan mata kuliah pilihan yang bertujuan untuk membekali mahasiswa dalam mengembangkan diri di masyarakat. Jumlah mata kuliah pilihan yang disediakan pada kurikulum pendidikan Seni Tari sebanyak 23 mata kuliah (sejumlah 14 sks). Adapun matakuliah pilihan yang disediakan:

1) Bahasa Jawa, bahasa Mandarin, bahasa Jerman, bahasa Perancis, dan bahasa Thailand

2) Penataan tari anak, public relation, dan filsafat seni

3) Tata busana tari anak, pengemasan pertunjukan, dan tari Kalimantan

4) Pengkajian lakon, tari etnik nusantara, dan business networking

5) Permainan tradisional anak, manajemen pemasaran, dan teknik penjiwaan

6) Psikologi anak dan remaja, manajemen pengelolaan sanggar, dan tari mancanegara

7) Musik tari anak, pengembangan produk kreatif, dan drama tari tradisiona

Mata kuliah pilihan ini mulai ditempuh pada semester tiga, empat, lima, dan enam. Jumlah sks pada setiap semester berbeda-beda, pada semester tiga ada 4 sks, semester empat ada 4 sks, semester lima ada 2 sks, dan semester enam ada 4 sks.

Mata kuliah pilihan yang disediakan disesuaikan dengan profil lulusan yaitu: sebagai pendidik Seni Tari profesional, penari profesional, koreografer/penata tari profesional, wirahusahawan di bidang seni pertunjukan profesional.

\section{A. Hasil Evaluasi Kurikulum}

Dari paparan di atas tentang struktur dan sebaran mata kuliah pada kurikulum 2014 Jurusan Pendidikan Seni Tari, untuk itu evaluasi dilihat dari 3 hal yaitu: isi kurikulum (mata kuliah), sebaran mata kuliah, deskripsi mata kuliah. 
1. Isi Kurikulum (mata kuliah)

Kurikulum 2014 Jurusan Pendidikan Seni

Tari memuat 70 mata kuliah dengan total sks 145. Dalam rangka penyempurnaan isi kurikulum dilakukan evaluasi dengan melibatkan mahasiswa, alumni, dan stake holder. Sebelum diadakan pertemuan dengan para pemakai terlebih dahulu disosialisasikan kepada dewan dosen Jurusan Pendidikan Seni Tari untuk mendapatkan masukan. Hasil dari pertemuan ini ada beberapa masukan terhadap pemberian nama matakuliah seperti public relotion yang dianggap tumpang tindih dengan matakulaih manajemen pemasaran. Dari hasil pertemuan dewan dosen ini ditemukan kesepakatan bahwa kedua mata kuliah ini tetap harus dicantumkan dalam kurikulum dikarenakan secara keilmuan keduanya berbeda.

Tahap berikutnya dilakukan sosialisasi kepada alumni, stake holder dan mahasiswa. Adapun alumni dan stake holder yang diundang sejumlah 15 orang yang terdiri dari guru (SMP dan SMA/SMK) yang mengajar Seni Budaya dan kepala sekolah di lingkungan DIY. Wakil dari mahasiswa sebanyak 15 orang yang terdiri dari semester tiga, lima, dan tujuh.

Dari pertemuan dengan alumni dan stake holder ada beberapa rekomendasi yang diberikan terhadap kurikulum 2014 Program Studi Pendidikan Seni Tari. Berdasarkan hasil ujicoba kelompok kecil dengan alumni dan steke holder ini bahwa Kurikulum 2014 Prodi Pendidikan Seni Tari akan lebih mendukung lulusan di lapangan dengan mencantumkan mata kuliah lintas prodi (mata kuliah mayor/ minor). Dapat juga lebih dispesifikan menjadi mata kuliah Apresiasi Seni dimana muatan di dalam mata kuliah ini mencakup keempat bidang seni (tari, musik, teater, dan rupa). Ini disesuaikan dengan kebutuhan di lapangan bahwa guru seni tidak lagi sendiri-sendiri akan tetapi guru seni budaya yang harus menguasai keempat bidang seni tersebut atau minimal menguasai dua bidang seni. Selain mata kuliah Apresiasi Seni para alumni dan stake holder merekomendasikan untuk menambah mata kuliah koreografi, karena di lapangan (sekolah) pembelajaran seni tidak lagi hanya mempelajari tari bentuk namun pembelajaran lebih diarahkan pada pengembangan kreativitas anak. Oleh karenanya mata kuliah koreografi baik secara teori maupun praktik sangat penting dikuasai oleh mahasiswa sebagai calon guru seni.

Selain memberikan rekomendasi untuk mengusulkan mata kuliah yang dianggap menunjang sebagai calon guru seni, ada juga mata kuliah yang dianggap tidak perlu dimasukkan yaitu mata kuliah bahasa asing (Thailand, Jerman, Prancis, dan Mandarin). Penguasaan bahasa ini bisa didapatkan melalui pendidikan non formal seperti kursus. Selanjutnya ada mata kuliah yang dirasa tumpang tindih yaitu mata kuliah Psikologi Pendidikan dengan Psikologi Anak Remaja. Untuk mengantisipasi hal tersebut perlu dipertegas pada deskripsi mata kulaih.

Sementara dari hasil uji coba dengan kelompok mahasiswa didapatkan rekomendasi untuk profil lulusan bidang kepenarian (penari profesional) perlu ditambahkan mata kuliah olah tubuh. Mata kuliah ini berkotribusi untuk membentuk kesiapan tubuh penari agar dapat melakukan gerak dengan teknik yang tepat dan benar, baik dalam membawakan tari klasik maupun tari modern. Disamping itu menjadi penari profesional dibutuhkan kelenturan, keseimbangan, pengaturan pernafasan yang bagus, serta kekuatan yang berkaitan dengan kenceng dan kendor (penggunaan tenaga) di dalam bergerak. Menjadi penari profesional dirasa tidak cukup hanya menguasai banyak ragam gaya tari, namun mempersiapkan tubuh untuk mampu melakukan teknik gerak dari berbagai gaya tari menjadi sangat penting.

Berikutnya profil lulusan yang berkaitan dengan koreografer/penata tari profesional, hasil dari uji coba ini merekomendasikan untuk menambahkan mata kuliah koreografi. Materi koreografi ini dapat berupa koreografi kelompok kecil dan juga kelompok besar. Dengan demikian, diasumsikan dapat memberi bekal kepada para lulusan untuk dapat ikut bersaing baik dalam tingkat nasional maupun internasional 
2. Sebaran Mata Kuliah pada Setiap Semester Dari 145 sks yang tercantum pada kurtikulum 2014 dalam pelaksanaannya terbagi menjadi delapan semester. Proporsi mata kuliah pada setiap semester dibuat seimbang antara teori dan praktik terutama pada semester $1-7$. Pada semester delapan mahasiswa sudah tidak dibebani untuk mengambil mata kuliah, pada semester ini mahasiswa tinggal mengambil tugas akhir.

Berdasarkan hasil uji coba dalam kelompok kecil pemakai kurikulum (mahasiswa) bahwa penempatan mata kuliah seminar sebaiknya setelah mahasiswa menempuh mata kuliah Penulisan Karya Ilmiah, Metodologi Penelitian, Metodologi Penelitian Seni. Tujuannya mahasiswa sudah memiliki pengalaman dalam menentukan ide, mengenal sistematika penulisan, dan wawasan keilmuan. Kurikulum 2014 ini sudah mengakomodasi hasil uji coba dengan mahasiswa dan mata kuliah seminar tercantum pada semester tujuh.

\section{Deskripsi Mata Kuliah}

Dari hasil uji coba dengan alumni dan stake holder didapatkan rekomendasi bahwa deskripsi mata kuliah PKN dan Pancasila, dan agama selain diberikan tentang keilmuan dari ketiga mata kuliah tersebut, dirasa perlu untuk mencantumkan tentang pendidikan karakter dan penguatan nasionalisme, sedangkan pada mata kuliah agama lebih ditekankan pada perbaikan etika dan moral. Penguatan ketiga hal tersebut dianggap penting untuk mewujudkan lulusan yang memiliki kepribadian yang tangguh. Untuk mata kuliah yang berkaitan dengan kependidikan seperti: mata kuliah psikhologi pendidikan, manajemen pendidikan, strategi pendidikan, media pendidikan, dan kurikulum perlu pada deskripsi perlu ditambahkan dengan kebutuhan di sekolah yang berkaitan dengan seni budaya. Dengan demikian para lulusan yang memilih sebagai guru seni (seni budaya) akan semakin percaya diri dalam mengembangkan diri dilingkungan tempat bekerja. Untuk deskripsi mata kuliah penilaian pembelajaran tari selain penilaian pengetahuan dan keterampilan perlu dimasukan penilaian tentang sikap untuk membentuk karakter desiplin dan menghargai orang lain.

Hasil uji coba dengan mahasiswa untuk deskripsi mata kuliah bahasa Inggris perlu ditambahkan tentang kemampuan berkomunikasi. Berkaitan dengan profil lulusan kepenarian (penari profesional) bahwa kemampuan berkomunikasi dengan bahasa Inggris sangat dibutuhkan apabila berhadapan dengan orang asing dalam kegiatan-kegiatan tertentu. Sedangkan untuk mata kuliah kewirahusaan deskripsi mata kuliah perlu ditambahkan tentang pengelolaan sanggar. Pada umumnya mahasiswa pada semester tiga sudah mulai berwirausaha dengan membuka sanggar tari untuk masyarakat umum yang dikelola baik secara perorangan maupun kelompok.

Pada bagian lain mahasiswa memberikan respon pada mata kuliah pendokumentasian tari, hasil dari uji coba menunjukkan sebaiknya di dalam deskripsi dicantumkan pada pembuatan dokumentasi tari-tarian yang telah ada. Mengingat tari-tarian baik yang klasik, kerakyatan, dan kreasi baru jumlahnya cukup banyak. Dari hasil pendokumentasian ini dapat dimanfaatkan sebagai bahan ajar baik oleh dosen, mahasiswa, lulusan/alumni. Bagi mahasiswa hasil dari pendokumentasian ini dapat dimanfaatkan untuk belajar secara mandiri dengan demikian dapat meningkatkan prestasi belajarnya.

\section{KESIMPULAN}

Berdasarkan hasil penelitian di lapangan terhadap evaluasi kurikulum 2014 Program Studi Pendidikan Seni Tari ada tiga materi yang dikaji yaitu: isi kurikulum, sebaran mata kuliah, dan deskripsi mata kuliah. Dilihat dari isi kurikulum mata kuliah yang dimunculkan telah mengacu pada profil lulusan dan untuk penguatan kompetensi lulusan dicantumkan mata kuliah pilihan. Sementara untuk sebaran mata kuliah telah mempertimbangkan masa tempuh untuk menyelesaikan studi yaitu empat tahun. Pada semester delapan mahasiswa tinggal menempuh Mata kuliah Tugas Akhir. Untuk pembentukan karakter yang berkaitan dengan etika, moral, dan nasionalisme 
dimunculkan pada setiap deskripsi mata kuliah baik mata kuliah teori maupun mata kuliah praktik.

Berbagai usaha dilakukan oleh Program Studi Pendidikan Seni Tari untuk menghasilkan lulusan yang memiliki kompetensi yang mampu berdaya saing dilapangan. Untuk itu telah ditawarkan mata kuliah pilihan dan juga mata kuliah lintas prodi seperti seni musik, rupa,dan seni kriya.

Dari hasil penelitian terhadap evaluasi kurikulum 2014 Program Studi Pendidikan Seni Tari ada beberapa hal yang perlu dipertimbangkan sebagai berikut:

1. Hasil dari evaluasi kurikulum yang dilakukan oleh Tim peneliti ini diharapkan dapat dijadikan bahan pertimbangan di dalam penyempurnaan kurikulum pada tahun-tahun berikutnya.

2. Penyusunan kurikulum sebaiknya selalu melibatkan pemakai (mahasiswa), alumni (guru), stake holder (pengguna).

3. Evaluasi kurikulum sebaiknya diadakan secara periodik agar dapat menyesuaikan dengan perkembangan kebutuhan masyarakat.

\section{DAFTAR PUSTAKA}

Apriyanto, Y. dkk. (2008). "Kearifan Lokal dalam Mewujudkan Pengelolaan Sumberdaya Air yang Berkelanjutan". Makalah pada PKM IPB, Bogor.
Arikunto, Suharsimi, dkk. 2007. Evaluasi Program Pendidikan. Jakarta: Bumi Aksara.

Catanese, A. J. \& Snyder, J. C. (1991). Pengantar Arsitektur. Jakarta: Penerbit Erlangga

Ellen, Roy. The Cognitive Geometry of Nature A contextual Approach, dalam P. Descola and G. Palsson (eds.), Nature and society: Anthropological Perspectives. London: Routledge London. http://lucy.ukc.ac.uk/ Rainforest/cog_intro.html, diakses 3 Juni 2007.

Hadi, Samsul, dkk. 2011. Metode Riset Evaluasi. Yogyakarta: Lakbang Grafika.

Keraf, A.S. (2010). Etika Lingkungan Hidup. Jakarta: Penerbit Buku Kompas.

Kurikulum 2014 berbasis KKNI. Pendidikan Seni Tari, Fakultas Bahasa dan Seni UNY.

Penjaminan Mutu UNY, 2014. Standar Mutu Universitas Negeri Yogyakarta. Yogyakarta: LPPMP UNY

Ridwan, N.A. (2007). "Landasan Keilmuan Kearifan Lokal". Jurnal Studi Islam dan Budaya. Vol.5, (1), 27-38.

\section{Sumber Internet}

http://asrofimuhammad 183. blogspot. co.id/2015/07/pentingnya-evaluasikurikulum-dalam.html 